\title{
Verificatie van data-integriteit, validiteit, en voorwaarden
}

\author{
Gjalt-Jorn Peters \& Ron Pat-El
}

2019-0\%-02 at 14:00:56 CEST (GMT+0200)

\section{Contents}

Verificatie van data-integriteit $\quad 2$

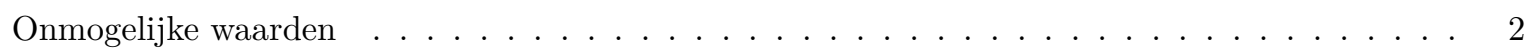

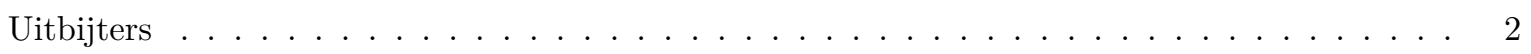

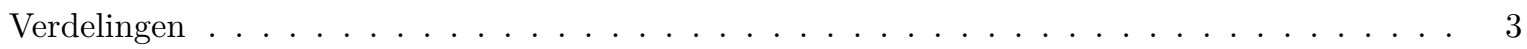

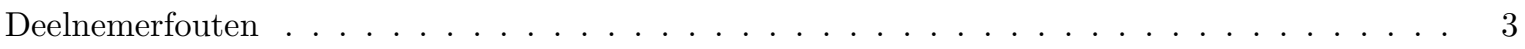

Studieplanning: verificatie van data-integriteit . . . . . . . . . . . . . . . . 3

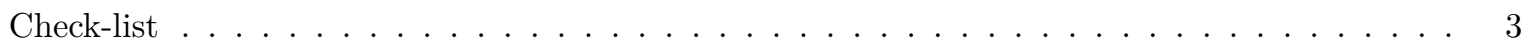

$\begin{array}{ll}\text { Verificatie van validiteit } & 4\end{array}$

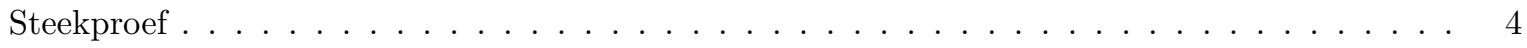

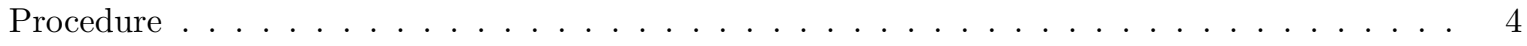

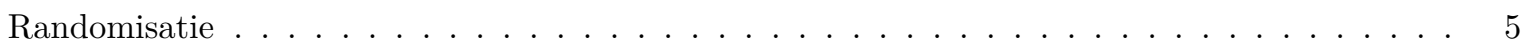

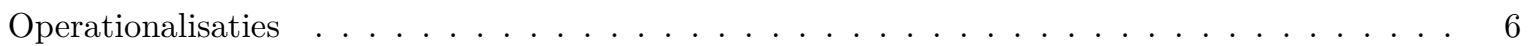

Studieplanning: verificatie van validiteit . . . . . . . . . . . . . . . . 7

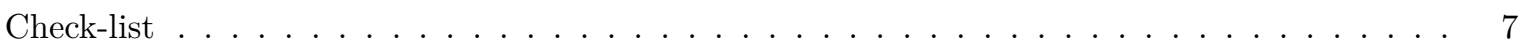

$\begin{array}{lr}\text { Verificatie van voorwaarden } & 9\end{array}$

Alle inferentiele analyses . . . . . . . . . . . . . . . . . . . . . . . 9

Univariate analyses . . . . . . . . . . . . . . . . . . . . . . . 9

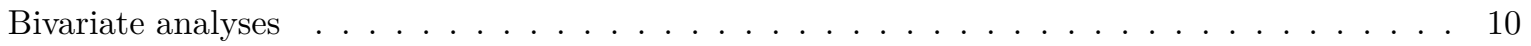

Multivariate analyses . . . . . . . . . . . . . . . . . . . . . . 12

Dit document is een Open Education Resource van de Open Universiteit. Het is gratis toegankelijk op PsyArXiv en heeft DOI 10.31234/osf.io/a5h9y.

Kwantitatieve studies hebben vaak tot doel om te schatten hoe sterk een of meer verbanden zijn of om een of meer hypothesen te toetsen. Om deze doelen te bereiken worden meestal statistische analyses uitgevoerd. Die hoofdanalyses maken echter maar een relatief klein deel uit van alle analyses die worden uitgevoerd: de meeste statistische analyses worden uitgevoerd om te verifieren of de hoofdanalyses wel uitgevoerd mogen worden.

Er zijn drie voorwaarden waaraan moet worden voldaan voordat het zinvol is om de hoofdanalyses uit te voeren:

1. De data-integriteit moet in orde zijn;

2. De validiteit van het studie-ontwerp en de operationalisaties moet in orde zijn; en

3. De data moeten voldoen aan de voorwaarden waaronder de hoofdanalyses geïnterpreteerd kunnen worden. 
Deze drie voorwaarden worden in dit document besproken. Als een van deze voorwaarden wordt geschonden is dit soms op te lossen, maar niet altijd. Als het niet op te lossen is, betekent dat dat de verzamelde dataset niet goed antwoord kan geven op de oorspronkelijke onderzoeksvragen. In dat geval is het vaak niet zinvol, en soms zelfs misleidend, om die hoofdanalyses desondanks uit te voeren. Bij schendingen die wel op te lossen zijn, wordt uitgelegd welke oplossingen voorhanden zijn.

Bij voorwaarden wordt onderscheid gemaakt tussen twee typen voorwaarden:

- "Deal breaker"-voorwaarden, oftewel voorwaarden waarvan schending het onmogelijk maakt om de betreffende analyse uit te voeren (op een wetenschappelijk integere manier);

- "Proceed at your own risk"-voorwaarden, oftewel voorwaarden die belangrijke gevolgen hebben voor de interpretatie van de betreffende analyse, maar waarbij de analyse wel zinnig kan zijn.

In deze uitleg wordt steeds gelinkt naar de Rosetta Stats website, waar de betreffende analyses worden uitgelegd in SPSS en R. Deze uitleg blijft dus op conceptueel niveau, en bevat zelf geen voorbeelden of scripts.

\section{Verificatie van data-integriteit}

Data-integriteit heeft betrekking op de kwaliteit van de data-verzameling. Een verzamelde dataset heeft data-integriteit als elk datapunt in die datareeks correspondeert met aspecten van de realiteit volgens de procedure gespecificeerd in het studie-ontwerp en de operationalisaties. Met andere woorden: werkte alles in de studie zoals het hoorde te werken?

Optimalisatie van de data-integriteit is een van de redenen waarom het belangrijk is om een studie vooraf te laten gaan door een pilot-studie. Pilot-studies zijn bedoeld om alles wat fout kan gaan van te voren uit te testen, zodat bijvoorbeeld niet blijkt dat deelnemers halverwege de studie te moe zijn om nog serieus mee te doen; of dat de apparatuur om reactietijden te registreren niet goed werkt; of dat de data die wordt verzameld via de smart watches van deelnemers niet wordt opgeslagen in een formaat dat niet goed te lezen is. Bij het verifieren van data-integriteit worden de datareeksen geïnspecteerd om te kijken of er indicaties zijn dat er iets fout ging tijdens de studie.

Er zijn vier zaken waarnaar wordt gekeken om de data-integriteit te verifieren.

\section{Onmogelijke waarden}

De eerste is of alle waarden mogelijk zijn. Als bijvoorbeeld een vragenlijst werd gebruikt waarbij de antwoordopties van een tot en met vijf lopen, en er staat een ander getal dan 1, 2, 3, 4 of 5 in de datareeks, dan ging daar iets fout, bijvoorbeeld bij het invoeren van papieren vragenlijsten. Als reactietijden worden gebruikt, en er wordt een reactietijd van 3 milliseconden geregistreerd, dan kan die reactietijd niet een respons zijn na verwerking van een stimulus. Maar onmogelijke waarden kunnen ook uit combinaties van responses bestaan, bijvoorbeeld als iemand specificeert al 12 jaar bij een bedrijf te werken, maar een leeftijd van 20 jaar opgeeft.

\section{Uitbijters}

Naast verdelingsvormen wordt vaak gekeken naar uitbijters: individuele datapunten die uitzonderlijk hoog of laag zijn in vergelijking met de rest van de datareeks. Deze uitbijters kunnen indicatief zijn voor onmogelijke waarden. Het kan ook zijn dat ze wel degelijk mogelijke waarden representeren, maar dat ze wel een onevenredige invloed uitoefenen op de hoofdanalyses. In dat geval is het goed om de hoofdanalyses te herhalen zonder deze deelnemers, om uit te sluiten dat de resultaten alleen bepaald worden door die uitbijters. 


\section{Verdelingen}

Verder is het belangrijk om altijd naar de verdelingen van de data te kijken. De vraag die dan moet worden beantwoord is of die verdelingen zijn zoals verwacht. De verdelingsvorm van elke datareeks in een steekproef benadert in principe de verdelingsvorm van die variabele in de populatie, met steekproeftoeval en meetfout 'toegevoegd'. Als bijvoorbeeld bekend is dat een variabele linksscheef is verdeeld in de populatie, maar de bijbehorende datareeks is rechtsscheef, normaal, of uniform, dan is dat een indicatie dat er misschien iets fout ging bij de dataverzameling. Het kan natuurlijk ook zo zijn dat de a priori verwachtingen over de vorm van de populatieverdeling niet blijken te kloppen: dat is ook belangrijk om te onthouden. Tot slot is voor sommige analyses belangrijk dat de verdeling van de afhankelijke variabele goed wordt gespecificeerd, dus dan is het goed om die te kennen.

- Histogrammen: https://rosettastats.com/histogram.html

- Boxplots: https://rosettastats.com/boxplot.html

\section{Deelnemerfouten}

Tot slot kan het zijn dat deelnemers niet goed opletten of zelfs opzettelijk foute data ingeven. Een bekend patroon is bijvoorbeeld 'straightlining', waarbij deelnemers bijvoorbeeld alle vragen in een arrayvraag met de laagste of juist de hoogste antwoordoptie beantwoorden, of soms in een kris-kras patroon de vragen beantwoorden. In $\mathrm{R}$ is er een package speciaal hiervoor, het careless package. In SPSS zijn geen eenvoudige oplossingen beschikbaar.

\section{Studieplanning: verificatie van data-integriteit}

Het verifieren van de data-integriteit wordt veel makkelijker als a priori (dus voordat de dataverzameling startte) is nagedacht over de verwachtingen die er op dat oment zijn met betrekking tot hoe de te verzamelen datareeksen eruit zullen zien. Daarom worden deze verwachtingen voor elke variabele van te voren besproken en gedocumenteerd. Bovendien is dit het moment om te besluiten welke afwijkingen van die verwachtingen acceptabel zijn of niet. De criteria die dan worden geformuleerd kunnen dan worden onderbouwd. Het is later natuurlijk mogelijk om van die planning af te wijken, ook steeds weer voorzien van een onderbouwing.

Als van te voren niet is gespecificeerd wanneer data worden aangepast of verwijderd (wat de voorwaarden precies zijn) en hoe (welke procedures zullen worden toegepast), dan kan dit ook achteraf worden besloten. Echter, omdat wetenschappers mensen zijn, en mensen vatbaar zijn voor verstoring van hun redeneringen, is er dan een aanzienlijk risico dat de keuzes die achteraf worden gemaakt deels gebaseerd zijn op de observaties in de data. Dit schaadt de betrouwbaarheid van die keuzes: de kans dat die dan bewust of onbewust anders worden gemaakt om de patronen in de data beter aan te laten sluiten bij het wereldbeeld of de verwachtingen van de onderzoeker is dan aanzienlijk. Daarom is het belangrijk om hier altijd van te voren over na te denken, en de keuzes, voorzien van onderbouwing, in een preregistratie vast te leggen.

\section{Check-list}

Deze check-list kan bij de planning van een studie worden gevolgd om vast te leggen wat tijdens de data-screening gedaan moet worden.

Bepaal voor elke datareeks die verzameld gaat worden welke waarden mogelijk zijn.

$\square$ Bepaal welke procedure wordt gevolgd als onmogelijke waarden worden aangetroffen.

Bepaal voor elke variabele wanneer waarden als uitbijters worden gezien.

$\square$ Bepaal welke procedure wordt gevolgd als uitbijters worden aangetroffen.

$\square$ Bepaal welke verdeling elke variabele zou moeten hebben.

$\square$ Bepaal welke procedure wordt gevolgd als variabelen anders verdeeld zijn.

$\square$ Bepaal wanneer responsen van deelnemers worden beschouwd als deelnemerfouten.

$\square$ Bepaal welke procedure wordt gevolgd als deelnemerfouten worden aangetroffen. 
Houd er rekening mee dat bij datascreening geen nulhypothesesignificantietoetsing (NHST) kan worden gebruikt. Er worden immers geen uitspraken gedaan over de populatie, maar over de steekproef. Let daarom op dat de voorwaarden, als die in kwantitatieve termen worden vastgelegd, worden beschreven in termen van de relevante schaaleenheden, of gestandaardiseerde versies hiervan, als bijvoorbeeld met $z$-waarden wordt gewerkt.

Er zijn heel veel mogelijke oplossingen voor problemen met data-integriteit. Hier worden een aantal veel gebruikte oplossingen genoemd.

- Bij onmogelijke waarden, uitbijters, of deelnemerfouten:

- De betreffende deelnemers worden verwijderd uit de dataset;

- De betreffende datapunten worden verwijderd uit de dataset (door ze op 'missing' of NA te zetten);

- De betreffende datapunten worden beschouwd als missende data, vervangen met een methode voor imputatie van missende data.

- Bij problematisch afwijkende verdelingsvormen:

- De variabele wordt niet verder geanalyseerd;

- De datareeks wordt getransformeerd.

Welke procedure ook wordt gekozen, het is belangrijk dat deze wordt uitgevoerd via commandos' in het analyscript, en worden voorzien van commentaar met uitleg. Alle bewerkingen die op de data worden uitgevoerd, van het inladen van de 'allerruwste' data tot en met de analyses voor de uiteindelijke resultaten, moeten worden gedocumenteerd. Hoewel dit in principe ook beschrijvend kan, is exacte reproductie dan vaak niet mogelijk.

\section{Verificatie van validiteit}

Als de data-integriteit is geverifieerd en in orde is, kan de validiteit van het ontwerp en van de operationalisaties worden geverifieerd. Er zijn vier mogelijke bedreigingen voor de validiteit van een studie: de steekproef, de procedure, de randomisatie, en de operationalisaties.

\section{Steekproef}

Als een studie wordt ontworpen, wordt bepaald welke populatie onderzocht gaat worden, en op basis hiervan wordt de wervingsprocedure ontwikkeld. Deze wervingsprocedure heeft tot doel een steekproef te werven die representatief is voor die populatie. Dit gebeurt meestal door willekeurige leden uit die populatie te selecteren voor de steekproef. Als de werving minder aselect was, of als de werving er niet in slaagde uit de doelpopulatie te werven, dan bedreigt dat de externe validiteit van een studie. De populatie waarover uitspraken worden gedaan is dan niet langer de doelpopulatie, maar een andere populatie. Daarom is het belangrijk om de wervingsprocedure goed in de gaten te houden en kan het handig zijn om een aantal kenmerken van de steekproef te vergelijken met die van de doelpopulatie om te verifieren of externe validiteit geborgd is.

Hiervoor geldt ook weer dat van te voren duidelijk moet zijn naar welke variabelen wordt gekeken, en welke afwijkingen acceptabel zijn. En ook geldt weer dat het goed is om dit van te voren vast te leggen in een preregistratie, met onderbouwing voor de gekozen criteria (i.e. naar welke variabelen wordt gekeken, en welke effectgroottes worden beschouwd als indicatief voor een nonrepresentatieve steekproef?) en procedure (i.e. wordt er niets gedaan, of worden data verwijderd, of worden data gewogen, of wordt op een andere manier omgegaan met de verlaagde representativiteit).

\section{Procedure}

Vanuit het oogpunt van de deelnemers bestaat de deelname aan een studie uit een serie handelingen. Die handelingen betreffen de toepassing van de operationalisaties (manipulaties en/of meetinstrumenten). 
Het is belangrijk dat die procedure voor alle deelnemers zoveel mogelijk gelijk is, en dat die procedure voor alle deelnemers accuraat en volgens planning wordt gevolgd. Als op een systematische manier van de procedure wordt afgeweken kan dit de validiteit van het studieontwerp in gevaar brengen. Als op een niet systematische manier van de procedure wordt afgeweken, manifesteert dit zich in extra errorvariantie, waardoor de analyses die van te voren zijn uitgevoerd om te bepalen hoeveel deelnemers nodig zijn niet langer kloppen, en er te weinig deelnemers worden geworven. Daarom is het belangrijk om goed op te letten dat de procedure goed wordt gevolgd. Dit kan bijvoorbeeld door proefleiders notities te laten maken. Als data online worden verzameld, bijvoorbeeld met LimeSurvey, kan worden gekeken hoe lang deelnemers met elke pagina bezig zijn, om zo te controleren of mensen niet halverwege pauzeren zonder dat dat de bedoeling is.

\section{Randomisatie}

Bij experimenteel onderzoek is een bijzonder deel van de procedure de randomisatie. Het is belangrijk dat die volledig 'at random' plaatsvindt. Dit word bepaald bij het plannen en opzetten van de studie: er kan bijvoorbeeld data van https://random.org worden gebruikt, of een random-nummer-generator in software. Als de randomisatie goed is verlopen, is het zeker dat de uitkomsten in de studie geen zogenaamde 'bias' kunnen bevatten: geen systematische afwijkingen. Onder aanname dat de overige aspecten van het ontwerp en de operationalisaties (dus de meetinstrumenten en de manipulaties) valide zijn, is het dan mogelijk om statistische modellen te gebruiken om conclusies te trekken over het effect van de manipulatie(s). Of de randomisatie lukt of niet hangt af van de procedure: er bestaan geen analyses die dit kunnen controleren. Als de procedure goed is gekozen, is adequate randomisatie gegarandeerd.

Dat randomisatie goed verloopt, en er dus geen systematische verschillen tussen de groepen deelnemers kunnen bestaan, betekent dat het studie-ontwerp geen 'bias' kan bevatten: hoewel in enkele studies de groepen deelnemers kunnen verschillen (bijvoorbeeld op de afhankelijke variabele), zullen die verschillen over alle studies normaal verdeeld zijn, met als gemiddelde nul.

In elke afzonderlijke studie is het nog wel mogelijk dat de groepen, waarnaar deelnemers zijn gerandomiseerd, verschillen. Dit kan niet worden getoetst met nulhypothesetoetsing: de daar verkregen $p$ waarde drukt de kans uit dat de gevonden effectgrootte wordt gevonden aangenomen dat in de populatie de effectgrootte gelijk is aan nul. Echter, het is in dit geval al zeker dat in de populatie de effectgrootte nul is: de groepen bestaan niet uit deelnemers uit verschillende populaties, maar uit deelnemers uit dezelfde populatie die door toeval in de ene of de andere groep belanden. Verwerping van de nulhypothese is dus altijd een Type-1 fout: de nulhypothese kan nooit terecht worden verworpen.

In plaats daarvan wordt a priori, dus als de studie wordt geplanned, vastgesteld hoe sterk de groepen maximaal mogen verschillen. Met andere woorden: hoezeer moeten de groepen 'hetzelfde' zijn om nog als equivalent gezien te worden? Voor elke variabele waarvan het belangrijk is dat die equivalent is tussen groepen wordt die effectgrootte bepaald. Tijdens de analyse worden deze effectgroottes in de steekproef vervolgens berekend en vergeleken met de vooraf bepaalde grenswaarden. Als een of meer van de variabelen te zeer verschilt tussen groepen, betekent dat dat de groepen in deze steekproef niet voldoende equivalent zijn. Dat betekent dat niet goed conclusies getrokken kunnen worden op basis van deze studie.

Er is geen vorm van toetsing nodig, omdat deze vraag (zijn de groepen in deze steekproef gelijk?) niet de populatie betreft, maar de steekproef. De vraag is dus niet of geobserveerde patronen wellicht door kans komen - het is al zeker dat die patronen door kans komen. De vraag is of de geobserveerde patronen dermate verstorend zijn dat ze de validiteit van het ontwerp van de studie in gevaar brengen, en dat hangt af van de steekproefwaarden, en die kunnen rechtstreeks geobserveerd worden.

Overigens geldt altijd al dat geen conclusies getrokken kunnen worden op basis van een enkele studie: de rol van toeval is daarvoor te groot. Maar als, bijvoorbeeld, de afhankelijke variabele al voor de manipulatie verschilt tussen de groepen, dan kunnen de data uit die steekproef geen informatie meet leveren over de invloed van het gemanipuleerde construct op de afhankelijke variabele in die steekproef. Het is echter wel belangrijk om de resultaten van die studie te publiceren. Als deze resultaten niet worden gepubliceerd, geldt niet langer dat er geen 'bias' optreedt over studies heen. Zelfs de geaggregeerde schattingen zijn dan niet langer zuivere schattingen, want de ruis (de errorvariantie) is dan niet langer normaal verdeeld. 
Hoewel in dat geval publicatie van de resultaten dus niet minder belangrijk is, kunnen er in die publicatie niet goed conclusies worden getrokken over de manipulatie(s). Eventuele effecten die op de nameting worden waargenomen kunnen immers het gevolg zijn van de nonequivalentie bij het begin van de studie. Het is in zo'n situatie dus belangrijk om nog tentatiever te zijn dan normaal. Zoals aangegeven maakt die noodzakelijke tentativiteit de uitkomsten van de studie niet minder belangrijk. Omdat de garantie op afwezigheid van bias uitsluitend opgaat over meerdere studies, en als alle uitgevoerde studies worden meegenomen, zijn studies met nonequivalente groepen net zo cruciaal als studies waarbij randomisatie 'wel is gelukt'.

\section{Operationalisaties}

De operationalisaties zijn de combinaties van procedures, stimuli, en responsregistratie die de doelconstructen in een studie representeren. Er zijn twee typen operationalisaties: meetinstrumenten en manipulaties. Manipulaties bestaat alleen uit procedures en stimuli, terwijl meetinstrumenten ook specificaties bevatten voor responsregistratie. Veelgebruikte typen meetinstrumenten zijn vragenlijsten (waarbij bijvoorbeeld de vragen en antwoordschalen stimuli zijn, de bolletjes die deelnemers aankruisen de responsregistratie, en de procedurele specificaties vastleggen welke vragen in welke volgorde worden aangeboden) en reactietijdentaakjes (waarbij woorden of plaatjes de stimuli zijn, toetsenborden worden gebruik voor responsregistratie, en de procedurele specificaties vastleggen welke stimuli in welke volgorde worden aangeboden). Manipulaties kunnen verschillen van bijvoorbeeld vignettes of scenarios, waarbij deelnemers in verschillende groepen verschillende teksten lezen over hypothetische situaties, via blootstelling aan video- of audiofragmenten, tot volledige gedragsveranderingsinterventies of zelfs een serie van twaalf therapiesessies.

\section{Meetinstrumenten}

Meetinstrumenten zijn valide als ze het doelconstruct meten. Dit betekent twee dingen:

- ten eerste moeten scores van deelnemers in de datareeks die het meetinstrument oplevert worden bepaald door dat doelconstruct; en

- ten tweede moeten die scores niet worden bepaald door andere constructen.

Als een datareeks niet correspondeert met het doelconstruct van het betreffende meetinstrument, kan samenhang van die datareeks met andere datareeksen niets zeggen over dat doelconstruct.

Validiteit is daarom cruciaal, maar ook heel moeilijk te bepalen. Omdat dit zo moeilijk is, gebeurt dit vaak in aparte studies. Een meetinstrument dat grondig is onderzocht en waarvan de validiteit aannemelijk is wordt ook wel gevalideerd genoemd. Echter, validiteit is geen kenmerk van een meetinstrument: het is een kenmerk van de toepassing van een meetinstrument in een steekproef. Neem bijvoorbeeld een Nederlandstalige vragenlijst om impulsiviteit te meten die is gevalideerd in een grote studie met deelnemers uit alle twaalf Nederlandse provincies. Als die vragenlijst wordt toegepast in Hongarije zal het geen valide meetinstrument voor impulsiviteit zijn. Als die vragenlijst twintig jaar later in Nederland wordt toegepast is de validiteit ook aangetast; taal en interpretatie van taal veranderen over tijd. Een gevalideerd meetinstrument kan dus in een willekeurige steekproef toch niet valide zijn.

De validiteit van meetinstrumenten kan van te voren in een aparte studie in dezelfde populatie worden onderzocht. Door de cognitieve validiteit te onderzoeken, en naar samenhang met andere variabelen zoals gedrag of andere constructen te kijken, en door te kijken of de antwoorden op de vragen in de vragenlijst met elkaar samenhangen zoals in andere populaties, kan dan worden vastgesteld of het aannemelijk is dat dat meetinstrument in de doelpopulatie valide is. Vervolgens kunnen in de eigenlijke studie de verdelingen van de datareeksen voor elke vraag, en de correlaties tussen die datareeksen, weer worden bekeken en worden vergeleken met diezelfde statistieken uit andere steekproeven.

\section{Manipulaties}

Als de validiteit van de meetinstrumenten aannemelijk is, kunnen deze worden gebruikt om de validiteit van de manipulatie(s) te verifieren. Net als bij meetinstrumenten betreft de validiteit bij manipulaties 
de mate waarin de manipulatie correspondeert met het doelconstruct, en uitsluitend het doelconstruct. In andere woorden: een valide manipulatie beinvloedt successvol het doelconstruct, en beinvloedt bovendien uitsluitend het doelconstruct, dus geen andere constructen (als wel andere constructen worden beinvloedt, kan nooit worden afgeleid dat verandering van het doelconstruct leidt tot verandering in andere constructen, wat in experimenten vaak de onderzoeksvraag is).

De validiteit van manipulaties kan worden geverifieerd door twee dingen te bepalen. Ten eerste, is de effectgrootte voor het verband tussen de manipulatie en de scores op een meetinstrument dat datzelfde construct operationaliseert voldoende groot? En ten tweede, is de effectgrootte voor het verband tussen de manipulatie en de scores op meetinstrumenten die andere constructen operationaliseren voldoende klein? Ook hiervoor geldt dat a priori opgesteld grenswaarden worden gebruikt. De vraag is immers niet of de manipulatie werkt in de populatie - als het goed is, is van alle operationalisaties, dus ook alle manipulaties, voorafgaande aan de studie vastgesteld dat ze in principe effectief zijn. Als dat niet zo is, is de operationalisatie nog niet klaar voor gebruik in onderzoek; de operationalisatie moet dan eerst zelf nog worden onderzocht om vast te stellen dat deze een betrouwbare en valide manipulatie is van het doelconstruct. De vraag is of de manipulatie in deze ene steekproef ook daadwerkelijk het doelconstruct heeft beinvloedt. Als dit door toeval niet is gebeurd in deze steekproef, kan immers niets worden afgeleid over een causaal verband tussen dat doelconstruct (dat immers niet is veranderd in de steekproef) en de afhankelijke variabele.

\section{Studieplanning: verificatie van validiteit}

Net als bij het plannen van de verificatie van data-integriteit geldt ook bij de verificatie van de validiteit van de studie (i.e. van de steekproef, het ontwerp, en de operationalisaties) dat van te voren moet worden vastgesteld welke afwijkingen acceptabel zijn. Of accurater: de procedure die wordt gevolgd moet duidelijk zijn, en deze moet a priori worden vastgelegd in een preregistratie om het risico te elimineren dat de keuzes met betrekking tot de te hanteren criteria worden gebaseerd op patronen in de data.

\section{Check-list}

Deze check-list kan bij de planning van een studie worden gevolgd om vast te leggen wat tijdens de data-screening gedaan moet worden.

Bepaal naar welke variabelen wordt gekeken om te bepalen of de werving heeft geresulteerd in een representatieve steekproef.

$\square$ Bepaal welke waarden voor elk van de variabele, of voor combinaties van die variabelen, acceptebel zijn, en welke indicaties zijn dat de wervingsprocedure niet heeft geresulteerd in een representatieve steekproef.

$\square$ Bepaal welke procedure wordt gevolgd als de steekproef op een or meerdere variabelen niet representatief is voor de doelpopulatie.

$\square$ Bepaal hoe wordt geregistreerd of de procedure voldoende nauwgezet wordt gevolgd.

$\square$ Bepaal hoe wordt bepaald of er te veel variatie in de gevolgde procedure is, of er te veel is afgeweken van de ontworpen procedure bij (een deel van) de deelnemers.

$\square$ Bepaal welke procedure wordt gevolgd als het aannemelijk is dat de procedure onvoldoende nauwgezet is gevolgd.

$\square$ Als een of meer van de hypothesen of onderzoeksvragen in de studie causaliteit betreft, en er dus een experimentele opzet wordt gebruikt, bepaal dan op welke variabelen de twee (of drie, of vier, etc) equivalent moeten zijn.

$\square$ Als een experimentele opzet wordt gebruikt, bepaal dan hoe sterk de groepen mogen verschillen op de relevante variabelen voordat ze als nonequivalent worden beschouwd.

$\square$ Als een experimentele opzet wordt gebruikt, bepaal dan welke procedure wordt gevolg als de validiteit van de manipulatie is aangetast omdat de groepen niet equivalent zijn op alle relevante variabelen.

$\square$ Bepaal hoe de validiteit van elk meetinstrument in de gebruikte steekproef wordt geverifieerd.

$\square$ Bepaal per meetinstrument wanneer wordt geconcludeerd dat dat meetinstrument niet valide is.

$\square$ Bepaal welke procedure wordt gevolgd als een of meerdere meetinstrumenten in deze steekproef niet valide zijn.

$\square$ Bepaal hoe de validiteit van elke manipulatie in de gebruikte steekproef wordt geverifieerd. 
Bepaal per manipulatie wanneer wordt geconcludeerd dat die manipulatie niet valide is.

$\square$ Bepaal welke procedure wordt gevolgd als een of meerdere manipulaties in deze steekproef niet valide zijn.

Houd er rekening mee dat bij datascreening geen nulhypothesesignificantietoetsing (NHST) kan worden gebruikt. Er worden immers geen uitspraken gedaan over de populatie, maar over de steekproef. Let daarom op dat de voorwaarden, als die in kwantitatieve termen worden vastgelegd, effectgroottes betreffen, en geen $p$-waarden.

Er zijn geen echte oplossingen voor schendingen van de validiteit van het studie-ontwerp. Wat wel nog overwogen kan worden wordt hieronder puntsgewijs besproken.

- Als de wervingsprocedure niet resulteerde in een steekproef die representatief is voor de doelpopulatie, is dit een probleem omdat het duidt op selectiebias: de deelnemers uit de doelpopulatie die niet meedoen verschillen waarschijnlijk van de deelnemers die wel meedoen, op onbekende manieren. Omdat dit onbekende manieren zijn, is er maar een echte oplossing voor: de dataverzameling herhalen. Dat is niet altijd mogelijk, maar er zijn wel procedures die gevolgd kunnen worden die het probleem (dat per definitie een onbekende omvang heeft) met een onbekende mate verminderen. Een procedure is om de deelnemers te wegen zodat de steekproef, op de variabelen die zijn gemeten, na weging wel representatief is. Voor zover de variabelen die samenhangen met de selectiebias dan samenhangen met die variabelen op basis waarvan wordt gewogen, wordt eventuele selectiebias dan verminderd. Een andere procedure is om een steekproef uit de steekproef te nemen; door willekeurig een aantal deelnemers te verwijderen die aan bepaalde criteria voldoen kan de steekproef worden aangepast om alsnog dezelfde samenstelling te hebben als de populatie. Hiervoor geldt echter ook dat niet bekend is in welke mate het probleem wordt opgelost. Een laatste procedure is de dataverzameling niet te herhalen, maar extra data te verzamelen, om zo de disbalans te proberen te herstellen.

- Als de procedure onvoldoende nauwgezet is gevolgd voor een aantal deelnemers, kan overwogen worden die deelnemers te verwijderen uit de analyse. Dit is zinnig als de afwijkingen in de procedure niet samenhangen met deelnemerkenmerken. Als afwijkingen in de procedure bijvoorbeeld optreden als deelnemers op een bepaalde manier reageren, dan hangt die reactie samen met een onbekend aantal andere variabelen, waardoor weer selectiebias optreedt als die deelnemers worden verwijderd. Als de verstoringen helemaal niet samenhingen met deelnemerkenmerken, dan kunnen de deelnemers waarbij verstoringen optraden veilig worden verwijderd.

- Als in een experimentele opzet de randomisatie 'niet lukte', oftewel, als deze steekproef een van de steekproeven was waarbij de groepen na randomisatie duidelijk verschilden, dan is hier geen oplossing voor. Het is mogelijk om variabelen als covariaat op te nemen, maar die beslissing mag niet afhangen van geobserveerde patronen in de data; er moet dan dus van te voren zijn besloten dat dit gebeurd. Als de groepen door de randomisatie van elkaar verschillen, dan kan een deel van de bias die daardoor wordt geïntroduceerd worden verminderd met die covariaten. Het is echter onbekend hoeveel, en de validiteit blijft dus bedreigd. Echter, dat geldt alleen voor conclusies op basis van die ene studie. Gegeven dat conclusies op basis van enkele studies eigenlijk moeten worden vermeden, is dit dus geen groot probleem. In een meta-analyse van een set replicaties zal deze 'bias' verdwijnen.

- Als de validiteit van een operationalisatie (een meetinstrument of een manipulatie) is geschonden, dan correspondeert de datareeks die wordt geleverd door die operationalisatie (of die in de dataset wordt ingevoerd om aan te geven in welke conditie deelnemers zaten, in het geval van een manipulatie) niet langer met het doelconstruct. Hierdoor is het niet langer mogelijk om conclusies te trekken over dat doelconstruct op basis van verbanden van andere datareeksen met deze datareeks. Hier is geen oplossing voor. Omdat dit niet opgelost kan worden, is het heel belangrijk om operationalisaties pas in een studie te gebruiken als deze grondig zijn onderzocht in de doelpopulatie. Het moet duidelijk zijn dat een operationalisatie cognitieve validiteit heeft in de doelpopulatie, en dat deze valide is (dat een meetinstrument het doelconstruct meet, en alleen het doelconstruct; en dat een manipulatie het doelconstruct manipuleert, en alleen het doelconstruct). 


\section{Verificatie van voorwaarden}

De voorwaarden van analyses verschillen van analyse tot analyse. In deze sectie worden van de analyses in het bachelorprogramma Psychologie van de Open Universiteit uitgelegd aan welke voorwaarden de te analyseren data moeten voldoen om de analyse te kunnen gebruiken.

Voor deze voorwaarden geldt weer dat het belangrijk is om voordat de dataverzameling start, te bepalen wanneer de in de steekproef geobserveerde patronen worden beschouwd als indicaties dat de voorwaarden worden geschonden. Door deze criteria en de te volgen procedure in geval van schending van een of meer criteria van te voren vast te leggen in de preregistratie wordt weer voorkomen dat de criteria deels tot stand komen op basis van de geobserveerde patronen in de data. Een bijkomend voordeel is dat als deze criteria en procedures allemaal zijn vastgelegd in de preregistratie, deze alleen nog hoeven te worden uitgevoerd als de data eenmaal binnen zijn. Als de dataverzameling eenmaal start is het moeilijkste werk dus al gedaan: de preregistratie vormt een stappenplan voor de analyses, dat alleen nog uitgevoerd hoeft te worden. Natuurlijk kunnen er twijfelgevallen voorkomen, of patronen waarop niet is geanticipeerd, dus het is wel belangrijk om te blijven opletten. Bovendien is het altijd mogelijk om af te wijken van de preregistratie. Dit kan dan met onderbouwing worden uitgelegd in de analysescripts of in het manuscript.

Sommige voorwaarden golden lange tijd, maar zijn inmiddels achterhaald. Om verwarring te voorkomen (gegeven dat zulke achterhaalde voorwaarden in andere bronnen soms nog wel worden behandeld alsof ze nog geldig zijn) worden achterhaalde voorwaarden hier ook kort besproken, en wordt uitgelegd waarom ze achterhaald zijn.

\section{Alle inferentiele analyses}

Het doen van uitspraken over een populatie op basis van een steekproef heet ook wel inferentie (je leidt uit de steekproef iets af over de populatie). Inferentiele statistiek vereist altijd dat de steekproef aselect is gekozen uit de populatie. Met andere woorden, elk lid van de populatie moet evenveel kans hebben om in de steekproef te belanden. Als dit niet het geval is, en er is sprake van bijvoorbeeld zelfselectie omdat wordt geworden via links op websites of social media, dan is niet bekend in hoeverre de steekproef representatief is voor de populatie. Deze eerste aanname, dat de steekproef aselect is, geldt dus voor alle inferentiele analyses. Overigens is dit gelukkig geen deal-breaker, maar als een steekproef niet echt aselect is, dan is het wel heel belangrijk om je bij de interpretatie van alle analyses af te vragen of de patronen die je ziet verklaard kunnen worden door selectiebias in je steekproef.

\section{Univariate analyses}

Univariate analyses zijn analyses waarin maar één variabele varieert. Dit betreft dus analyses die op een enkele datareeks worden uitgevoerd. Deze analyses worden behandeld in cursus PB0202, Onderzoekspracticum inleiding data-analyse.

\section{Centrummaten}

Centrummaten zijn getallen die de centrale tendentie van een datareeks samenvatten. Zij vormen vaak een efficiënt middel om een datareeks te beschrijven, als tenminste aan de voorwaarden wordt voldaan.

\section{Het gemiddelde}

\section{- Deal-breakers:}

- Het gemiddelde kan alleen worden berekend voor kardinale datareeksen, dus datareeksen die het interval-niveau of het ratio-niveau hebben. Als een datareeks het ordinale of nominale meetniveau heeft, kan het gemiddelde niet worden berekend.

\section{- Proceed at your own risk:}

- Als een datareeks assymetrisch is verdeeld, dus linksscheef of rechtsscheef is, verschilt het gemiddelde van de modus (de top van de verdeling). Pas dus goed op bij interpretatie! 
- Bij uitzonderlijk kleine datareeksen (enkele tientallen datapunten of minder) is de steekproevenverdeling van het gemiddelde niet normaal verdeeld. In dat geval kan de reguliere methode om betrouwbaarheidsintervallen voor het gemiddelde te berekenen niet worden gebruikt, en moet in plaats daarvan bootstrapping worden gebruikt.

\section{De mediaan}

\section{De modus}

De modus kun je altijd noemen. Hier kleven geen voorwaarden aan. Hij is vaak niet heel informatief, maar er kan ook niets fout gaan.

\section{Bivariate analyses}

Bivariate analyses zijn analyses waarin precies twee variabelen varieren. Dit betreft dus analyses die op een twee datareeks worden uitgevoerd. Deze analyses worden behandeld in cursus PB0202, Onderzoekspracticum inleiding data-analyse. Deze zijn geordend aan de hand van het meetniveau van de twee datareeksen: kardinaal, ordinaal, of nominaal. Kardinale datareeksen zijn afkomstig van operationalisaties die hun doelconstruct op een interval of rationele schaal operationaliseren. Oridnale datareeksen zijn afkomstig van operationalisaties die hun doelconstruct op een categorische schaal operationaliseren, waarbij de mogelijke meetwaarden allemaal ten opzichte van elkaar te ordenen zijn op één dimensie, maar waarbij de onderlinge afstand tussen de meetwaarden onbekend of niet kwantificeerbaar is. Nominale datareeksen zijn afkomstig van operationalisaties die hun doelconstruct op een categorische schaal operationaliseren, waarbij de mogelijke meetwaarden niet te ordenen zijn ten opzichte van elkaar. Een speciaal geval zijn dichotome datareeksen, ook wel binaire datareeksen genoemd: omdat deze maar twee mogelijke meetwaarden betreffen, kunnen ze meestal als nominaal, ordinaal, of kardinaal worden gezien. Categorische datareeksen worden overigens ook wel discrete datareeksen genoemd, en deze termen worden meestal gebruikt voor datareeksen met meer dan twee categorieën.

\section{Twee kardinale datareeksen: Pearson's correlatie en enkelvoudige regressie-analyse}

Enkelvoudige regressie-analyse (verwarrend genoeg ook wel 'univariate regressie' genoemd, niet omdat er maar een variabele bij betrokken is (dat zijn er immers twee), maar omdat er maar een voorspeller is) is simpelweg een andere benadering van de Pearson correlatie. Deze wordt dus niet apart besproken; alle aannames die gelden voor de Pearson correlatie gelden ook voor de enkelvoudige regressie-analyse. De aannames van de Pearson correlatie zijn als volgt.

\section{Beide datareeksen hebben het kardinale niveau}

Als een of twee van de datareeksen ordinaal is, kan in plaats van de Pearson correlatie de Spearman correlatie worden gebruikt. Hiervoor gelden verder dezelfde aannames. Als een of twee van de variabelen nominaal is, kan de Pearson correlatie niet worden gebruikt. Als een of twee van de variabelen dichotoom is, kan de Pearson correlatie worden berekend, maar deze heet dan de puntbiseriële correlatie, en moet anders worden geïnterpreteerd. In dat geval kan beter Cohen's $d$ worden berekend.

\section{Het betreffende verband is lineair}

Om te verifiëren of het verband lineair is, kan een scatterplot worden besteld. Als de punten niet op een rechte lijn liggen (met daar omheen natuurlijk willekeurige variatie, de error), maar een curvilineair patroon lijken te volgen, kan de Pearon correlatie of de Spearman correlatie het verband tussen die twee variabelen niet goed representeren.

- Scatterplots: https://rosettastats.com/scatterplot.html 


\section{Het verband wordt niet verstoord door uitbijters}

Uitbijters kunnen univariaat zijn, maar ook bivariaat. Een bivariate uitbijter is een waarde die afwijkt van het patroon dat de andere datapunten in een datareeks volgen.

\section{Het verband wordt niet verstoord door afwijkende verdelingen}

Als twee variabelen verschillend zijn verdeeld, daalt de maximaal haalbare correlatie. Als de verdelingsvormen in de steekproef representatief zijn voor de verdelingsvormen in de populatie, dan is dit geen probleem; het verband kan dan immers nooit volledig zijn in de populatie. Als de verdelingsvormen echter afwijken van de verdelingsvormen in de populatie, dan is de correlatie die wordt gevonden in de steekproef niet langer representatief voor het verband in de populatie (hoewel dit meer een dataintegriteitsprobleem of een validiteitsprobleem is).

\section{- Deal-breakers:}

- De datareeksen zijn ordinaal of nominaal (waarbij dichotome datareeksen, omdat ze as interval-variabelen te beschouwen zijn, een uitzondering vormen). Of een datareeks ordinaal of interval is, is bij psychologische variabelen overigens vaak niet duidelijk. De aanname is bijna altijd dat de onderliggende variabele continue is, maar een gegeven operationalisatie kan soms toch ordinaal zijn. Er bestaan analysemethoden om dit te toetsen, zoals multidimensional scaling, maar die vallen buiten dit curriculum. Je kunt altijd Spearman's correlatie berekenen; die werkt prima voor ordinale variabelen.

- Als een verband nonlineair is (zoals te zien in de scatterplot) kun je geen gewone correlatie gebruiken.

\section{- Proceed at your own risk:}

- Bij uitbijters kan de correlatie worden verstoord: bestudeer de scatterplots en herhaal de analyse zonder uitbijter(s). Je kunt ook Spearman's correlatie berekenen; omdat die wordt berekend met de 'ranks' van de datapunten hebben uitbijters niet meer zo onevenredig veel invloed.

- Bij verdelingen die verschillen (e.g. een hele linksscheve verdeling en een normale verdeling) kan de correlatie nooit 1 of -1 worden. Maar deze verdelingen representeren misschien wel de verdelingsvorm in de populatie, waardoor die schatting alsnog accuraat kan zijn.

\section{Een dichotome datareeks en een kardinale datareeks: Cohen's $d$ en $t$-toetsen}

Cohen's $d$ en de $t$-toets delen veel aannames, dus ze worden samen beschreven.

\section{Een kardinale datareeks en een dichotome datareeks}

Zowel Cohen's $d$ als de $t$-toets maken gebruik van het feit dat een dichotome datareeks gebruikt kan worden om een kardinale datareeks in twee groepen te verdelen, waarna de gemiddelden van beide groepen berekend kunnen worden. Het berekenen van gemiddelden vereist een kardinale (interval, continue) datareeks. Als de ene datareeks niet kardinaal is maar ordinaal of nominaal, dan kan als effectgrootte Cramer's V worden berekend, en eventueel de $\chi^{2}$-toets worden gebruikt as nulhypothesesignificantietoetsing wordt toegepast. Als de ene datareeks wel kardinaal is, maar de andere datareeks ordinaal of nominaal, dan kan als effectgrootte $\omega^{2}$ worden berekend, en eventueel variantie-analyse worden gebruikt om de $F$-waarde te berekenen als nulhypothesesignificantietoetsing wordt toegepast.

\section{De gemiddelden worden niet bepaald door uitbijters}

Uitbijters kunnen een onevenredige invloed uitoefenen op zowel het gemiddelde als de standaard-deviatie. Als er dus uitbijters zijn, kunnen deze het gemiddelde in een groep enkelhandig zo sterk verhogen of verlagen dat er verbanden lijken te bestaan die ter niet zijn, of vice versa. 
Achterhaald: de steekproevenverdelingen van de gemiddelden in de twee groepen die worden gevormd door de dichotome datareeks zijn normaal

Aan deze aanname wordt altijd voldaan vanwege de centrale limietstelling. De enige situaties waarin je hier niet aan voldoet zijn als je steekproeven heel klein zijn. Echter, met zulke kleine steekproeven (enkele tientallen deelnemers) is het onmogelijk om Cohen's $d$ accuraat te schatten (met twee groepen van 30 deelnemers is het $95 \%$ betrouwbaarheidsinterval voor Cohen's $d$ ongeveer een hele standaarddeviatie breed, dus de breedte van dat interval is al een veelvoud van de effectgroottes die gangbaar zijn in psychologisch onderzoek), en als geen effectgrootte wordt geschat maar nulhypothesesignificantietoetsing wordt toegepast, is de power om zelfs een Cohen's $d$ van 0.5 aan te tonen (een zeldzaam groot effect in de psychologie) lager dan 50\%. Omdat zinvol onderzoek dus sowieso minstens richting de honderd deelnemers per groep vereist, garandeert de centrale limietstelling dat de steekproevenverdelingen van de gemiddelden normaal zijn verdeeld, hoe de populatieverdeling er ook uit ziet (en dus, hoe de verdeling van steekproefscores er ook uit ziet). Hoewel dit dus formeel een aanname is, speelt hij bij onderzoek met fatsoenlijke steekproefomvangen geen rol.

\section{Achterhaald: varianties in de groepen moeten gelijk zijn}

Er zijn twee $t$-toetsen: Student's $t$-toets en Welch's $t$-toets. De eerste vereist dat de varianties in beide groepen gelijk zijn. Echter, Welch's t-toets niet - deze corrigeert voor ongelijke varianties, in de mate die nodig is (dus, bij gelijke varianties zijn beide $t$-toetsen aan elkaar gelijk). Gebruik daarom standaard de Welch's $t$-toets, zodat het niet uitmaakt of de varianties verschillen.

\section{- Deal-breakers:}

- De enige deal-breaker bij de $t$-toets is als je niet een kardinale en een dichotome datareeks hebt (in andere woorden: als je niet twee gemiddelden wil vergelijken). Als je wel een dichotome en een kardinale datareeks hebt, kun je Welch's $t$-toets uitvoeren.

\section{- Proceed at your own risk:}

- Als er uitbijters zijn, herhaal de analyse dan ook zonder uitbijters.

- Als de variantie in een van beide groepen heel erg verschilt van de variantie in een andere groep, dan is dat geen probleem voor Welch's $t$-toets - maar, het kan wel betekenen dat er iets fout ging, als je dit niet verwacht. Waarom lijken de deelnemers in die ene groep zoveel meer op elkaar dan de deelnemers in de andere groep? Als je dat niet kunt verklaren, dan is dat een probleem.

- Ditzelfde geldt voor de verdelingsvormen. Dit gaat eigenlijk over de validiteit van je datareeksen: als je datareeksen niet verdeeld zijn zoals je verwacht dat de betreffende constructen in de populatie zijn verdeeld, dan ziet ofwel de populatie er heel anders uit dan je verwachtte (en moet je nadenken over de implicaties daarvan), ofwel je operationalisaties waren niet valide in jouw steekproef, en in dat geval kunnen de datareeksen die die operationalisaties hebben gegenereerd je dus niets meer vertellen over de constructen die ze hadden moeten meten (maar dus niet hebben gemeten).

Een categorische datareeks en een kardinale datareeks: Omegakwadraat en eenweg variantieanalyse

Twee categorische datareeksen: Cramer's V en $\chi^{2}$

Multivariate analyses

Meerweg variantieanalyse

Tussen-proefpersonen meerweg variantieanalyse zonder covariaten

\section{Tussen-proefpersonen meerweg variantieanalyse met covariaten}




\section{Binnen-proefpersonen meerweg variantieanalyse zonder covariaten}

\section{Split-plot meerweg variantieanalyse zonder covariaten}

\section{Multivariate regressie-analyse}

Voor multivariate regressie-analyse gelden dezelfde aannames die gelden voor univariate (enkelvoudige) regressieanalyse (dus: alle variabelen moeten een kardinaal meetniveau hebben (continue/interval/ratio), de verbanden moeten niet worden gedomineerd door uitbijters of verdelingen die te scheef, spits, of afgeplat zijn, en de verbanden moeten lineair zijn), plus nog een aantal aannames.

\section{Multivariate normaliteit}

Voor elke combinatie van alle voorspellers moeten de datareeksen normaal zijn verdeeld. Dit drukt de aanname uit dat er geen systematische verstoringen in de data zitten: dat er behalve de verbanden tussen de voorspellers en de afhankelijke variabele alleen 'ruis' is, en dat die ruis (de error) normaal is verdeeld. Deze aanname kan worden getoetst door de residuen te inspecteren: deze moeten grofweg normaal zijn verdeeld. Zie hiervoor de sectie 'Verdelingen' binnen 'Verificatie van data-integriteit'.

\section{Homoscedasciteit}

Als er homoscedasciteit is, is de variantie van de ene variabele onafhankelijk van de waarde van een (of meerdere) andere variabelen. Dan is die variantie dus altijd ongeveer hetzelfde. Bij heteroscedasciteit verschilt die variantie als functie van een andere variabele. Neem bijvoorbeeld leeftijd en lengte. De variantie in lengte neemt toe naarmate kinderen opgroeien: als ze worden geboren zijn ze allemaal zo ongeveer een halve meter. Babies van 45 centimeter tot 60 centimeter komen nog wel voor, maar meer dan 20 centimeter afwijking is zeer zeldzaam. Bij pubers en volwassenen is de variantie veel groter. In dat geval is er dus heteroscedasciteit. Het probleem van heteroscedasciteit is tweeledig.

Ten eerste wordt bij regressieanalyse de best passende lijn gezocht. "Best passend" is dan gedefinieerd als de lijn waarbij de afwijkingen van de datapunten het kleinst zijn. Hierbij krijgt elk datapunt hetzelfde gewicht. Echter, als die afwijkingen ergens veel groter zijn (bijvoorbeeld bij pubers in vergelijking met babies), dan krijgen de datapunten van pubers toch meer invloed. Een oplossing hiervoor is 'weighted least squares' regressie (deze valt buiten het curriculum).

Ten tweede wordt de standaardfout van de regressiecoefficient die die lijn beschrijft geschat, maar die schatting is gebiased onder heteroscedasciteit. Dit is ook een meer methodologisch/theoretisch probleem: als er geen homoscedasciteit is, dan is er dus geen niet 'een standaarfout'. De accuraatheid van de schatting van de regressielijn hangt dan immers af van de waarden van de voorspellers. Dit probleem kan ook worden opgelost met 'weighted least squares' regressie (die jammer genoeg dus buiten het curriculum valt).

\section{Geen (multi-)collineariteit}

Collineariteit betekent dat twee variabelen samenhangen in hun voorspelling van een derde variabele. Als bijvoorbeeld op een basisschool lengte en gewicht worden gemeten om leeftijd te voorspellen ${ }^{1}$, zullen deze drie variabelen allemaal samenhangen (in die populatie is leeftijd immers te beschouwen als een causaal antecedent, een oorzaak, van zowel lengte als gewicht). Omdat leeftijd zowel gewicht als lengte beinvloedt, is de voorspelling van leeftijd door lengte niet onafhankelijk van iemands gewicht. In een regressie-analyse waarbij lengte en gewicht als voorspellers worden opgenomen van leeftijd voorspellen lengte en gewicht dus zowel elkaar als leeftijd. Dit heet collineariteit.

\footnotetext{
${ }^{1}$ Overigens wordt soms gesteld dat in regressie-analyse de causale antecedenten (de oorzaken) de voorspellers moeten zijn, en het gevolg de afhankelijke variabele. Dit is een misverstand. Causaliteit zit in het design van een studie, niet in de analyse. Het is prima mogelijk, en soms wenselijk, om een causaal antecedent (een oorzaak) als afhankelijke variabele op te nemen; of om een casuaal consequent (een gevolg) als voorspeller op te nemen. Sterker nog, als alle variabelen psychologische variabelen zijn is dat onderscheid vaak moeilijk te maken. Als het doel van een studie is om causaliteit te onderzoeken, dan is altijd een experimenteel design nodig. Of dat wordt geanalyseerd met variantie-analyse of regressie-analyse hangt van andere dingen af, niet van de rol van een variabele in het design van de studie.
} 
Multi-collineariteit is hetzelfde fenomeen, maar dan met meer dan twee voorspellers. Het kan immers ook zo zijn dat er vier voorspellers zijn die geen van allen bivariaat sterk samenhangen, maar waarbij een van de vier door de drie anderen samen wel goed wordt voorspeld. Als het deel van die variabele dat goed wordt voorspeld door de drie anderen dan ook deel uitmaakt van het deel van die variabele dat de afhankelijke variabele voorspelt, dan is er sprake van multicollineariteit.

(Multi-)collineariteit is een probleem omdat overlap tussen voorspellers in hun voorspelling van de afhankelijke variabele door de analyse niet gescheiden kan worden. Het is immers niet bekend bij welke voorspeller dat 'overlappende stukje voorspelling' hoort. Dit betekent dat de overlappende voorspelling uit het model wordt verwijderd, wat zich manifesteert als een toename in de standaardfout van de voorspellers. Deze kunnen hierdoor minder goed worden geschat: ze hebben bredere betrouwbaarheidsintervallen (en, als nulhypothesesignificantietoetsing wordt toegepast, hogere p-waarden, oftewel, er is minder power). In andere woorden: deze grotere standaardfouten betekenen dat de waarden van de regressiecoefficienten van steekproef tot steekproef fors kunnen verschillen. Het wordt dus snel moeilijker om uitspraken te doen over die coefficienten, en dus over hoe sterk (en: of) de voorspellers samenhangen met de afhankelijke variabele.

Bij psychologische variabelen is een extra complicatie dat (multi-)collineariteit vaak betekent dat de operationalisaties van die variabelen deels dezelfde aspecten van de menselijke psychologie meten. Als de variantie in die overlap vervolgens uit de analyse wordt verwijderd, heeft de geschatte regressiecoefficient dus niet langer betrekking op het doelconstruct van die operationalisaties, maar van een onbekende subset van dat doelconstruct. Je weet dan dus niet meer wat de regressiecoefficienten representeren.

Multicollineariteit kan worden geinspecteerd door naar de tolerantie en de variance inflation factor (de VIF) te kijken. Deze kunnen voor elke voorspeller worden berekend, en ze zijn eigenlijk hetzelfde. De tolerantie is het complement van de $R^{2}$ die je krijgt als je de betreffende voorspeller zou voorspellen uit de andere voorspellers in een aparte regressieanalyse. Als je dus $20 \%$ van een voorspeller kunt voorspellen uit de andere voorspellers, dan is de $R^{2}$ in die regressieanalyse .20 , en dan is de tolerantie van die voorspeller in je oorspronkelijke regressieanalyse gelijk aan $1-0.20=0.80$. De variantie inflatie factor is de reciproke van de tolerantie. In dit geval is die dus $\frac{1}{0.80}=1.25$. Deze VIF is handig omdat hij uitdrukt hoeveel groter de standaardfout van deze voorspeller wordt door die (multi-)collineariteit. Een VIF van 1.25 valt nog mee: dan is de standaardfout dus 'maar' $25 \%$ groter. 